RECYT

Year 23 / No 36 / 2021 / 70-77

\title{
Prevalence of thyroid dysfunction and its relationship with the lipid profile in patients in hospital from Encarnación
}

\section{Prevalencia de disfunción tiroidea y su relación con perfil lípidico de pacientes del Hospital de Encarnación}

\author{
Edith N., Genéz Yeza ${ }^{1, *}$; Claudia N., Mir², ${ }^{2}$; Rocío M., Ares ${ }^{2,3}$; \\ Williams R., Pedrozo 2, 3; Graciela A., Bonneau²,3 \\ 1- Regional Hospital of Encarnación. Paraguay. \\ 2- Ministry of Public Health, Province of Misiones. Tucumán 2174, Posadas, Misiones. \\ 3- Faculty of Exact, Chemical and Natural Sciences. National University of Misiones. Félix de Azara 1552, Posadas, Misiones. \\ *E-mail: mati4edith@gmail.com
}

Abstract

Received: 18/02/2021; Approved 20/05/2021

Thyroid dysfunctions are a cause of morbidity and disability worldwide. Little information has been found on the prevalence of thyroid dysfunctions in Paraguay, so this study provides data on their presentation. The objective was to determine the prevalence of thyroid dysfunction and its relationship with the lipid profile in adult outpatients attending the laboratory of the Regional Hospital of Encarnación, during January-November 2016.

A descriptive cross-sectional study was performed, based on the review of 250 medical records, $84 \%$ of whom were women; the median age was 39 (35-47) years in men and 36 (32-43) years in women. Thirty percent were hypothyroid and $3 \%$ hyperthyroid; the most frequent thyroid dysfunction was subclinical hypothyroidism with $19 \%$. Highly significant differences were found for total cholesterol, LDL, VLDL and thyrotrophin between hypothyroid vs euthyroid, with the former having more atherogenic profiles. Logistic regression was used to assess the contribution of dyslipidaemia, finding a significant association with hypothyroidism (OR=3.24(1.81-5.81), $\mathrm{p}<0.001)$. Thirty-three percent of this population sample, 1 in 3 individuals, had thyroid dysfunction. These could be managed appropriately and further complications could be avoided.

Keywords: Thyroid dysfunction; Lipid profile; Hypothyroidism; Hypothyroidism; Hyperthyroidism; Euthyroidism; Subclinical hypothyroidism; Thyrotrophin; Dyslipidaemia.

\section{Resumen}

Las disfunciones tiroideas son causas de morbilidad y discapacidad a nivel mundial. Se ha encontrado escasa información sobre la prevalencia de estas en Paraguay, por lo que este trabajo aporta datos sobre su forma de presentación. El objetivo fue determinar la prevalencia de disfunciones tiroideas y su relación con el perfil lipídico en pacientes adultos ambulatorios que concurrieron al laboratorio del Hospital Regional de Encarnación, durante enero-noviembre del 2016.

Se realizó un estudio descriptivo-transversal, basado en la revisión de 250 historias clínicas, de las cuales $84 \%$ eran mujeres; la mediana de edad fue 39 (35-47) años en los hombres y 36 (32-43) años las mujeres. El $30 \%$ eran hipotiroideos y $3 \%$ hipertiroideos; la disfunción tiroidea de mayor frecuencia fue el hipotiroidismo subclínico, con un $19 \%$. Se halló diferencia altamente significativa para colesterol total, LDL, VLDL y tirotrofina entre los hipotiroideos vs eutiroideos, donde los primeros presentaban perfiles más aterogénicos. Se utilizó regresión logística para evaluar la contribución de la dislipemia, encontrándose asociación significativa con el hipotiroidismo $(O R=3,24(1,81-5,81)$, $\mathrm{p}<0,001)$. El $33 \%$ de esta muestra poblacional, 1 de cada 3 individuos, presentaron una disfunción tiroidea. Con los cuales se podría tener un manejo adecuado de estas y evitar posteriores complicaciones.

Palabras clave: Disfunciones tiroideas; Perfil lipídico; Hipotiroideos; Hipertiroideos; Eutiroideos; Hipotiroidismo subclínico; Tirotrofina; Dislipemia. 


\section{Introduction}

The follicular cells of the gland produce two main thyroid hormones (HT): Tetrayodothyronine (thyroxine, T4) and Triiodothyronine (T3), while the parafollicular or $\mathrm{C}$ cells secrete the polypeptide calcitonin, an important hormone for calcium metabolism as it inhibits bone resorption (1).

The growth and function of the thyroid gland are controlled by the hypothalamic-pituitary-thyroid axis. Hypothalamic thyrotropin-releasing hormone (TRH) stimulates thyrotrope cells in the anterior pituitary to produce serum thyrotropin (TSH) which, in turn, promotes thyroid gland growth and secretion of T3 and T4 hormones by the thyroid gland, both of which in turn inhibit, by negative feedback, TRH and TSH synthesis and thus maintain a stable blood level of T4 and T3 (2-4). T4 and T3 act on cells in almost all body tissues by combining with nuclear receptors and altering gene expression. Among their actions, HTs promote normal development of brain and somatic tissue in the foetus, newborn and during childhood; they regulate heart rate, myocardial contraction and relaxation, affect gastrointestinal motility, renal water clearance, regulate energy expenditure, heat generation, weight and lipid metabolism $(1,4)$

Thyroid dysfunction (TD) is one of the most prevalent pathologies in all periods of life and, as the action of thyroid hormones is pleiotropic, thyroid dysfunction can have multi-organ repercussions (5). Thyroid function is assessed by laboratory tests for the detection of TD or monitoring of pre-existing disorders. The most common conditions of thyroid morpho-function can be classified according to altered function: hypothyroidism (thyroid hypofunction) and hyperthyroidism (thyroid hyperfunction); or according to alterations in size: goitre and thyroid nodule (6) function is determined by testing TSH, T4 and T3, although there is much controversy, most professional societies suggest to use TSH to determine thyroid dysfunction in outpatients, provided that the assay used has a functional sensitivity equal to or less than $0.02 \mathrm{mIU} / \mathrm{L}$ (6-8)

Subclinical TD is defined as a functional disorder of the thyroid gland, asymptomatic and only detectable by hormonal laboratory tests, especially in middle-aged and older individuals, manifested by altered TSH concentrations and normal serum concentrations of free T3 and T4 (9-12). Hyperthyroidism (hyperT) is a clinical condition characterized by excessive serum T4 and T3, or both, with suppression of TSH (13). Once diagnosed, the cause must be investigated to establish treatment and prognosis. Probable causes include Grave's disease, toxic multinodular goitre, toxic adenoma, postpartum thyroiditis, subacute thyroiditis, pharmacological, often in patients taking synthetic levothyroxine as part of treatment for hypothyroidism, amiodarone, lithium, interferon $\alpha$, interleukin- 2 or a history of potassium iodide use or exposure to iodinated radiological contrast agents increase the likelihood of drugor iodine-induced hyperthyroidism (13).

Subclinical hyperthyroidism (HiperSC) is the asymptomatic or symptomless phase of any disease presenting with hyperT (13). Hypothyroidism (hypoT) is a clinical syndrome resulting from HT deficiency, which leads to a generalized slowing of metabolic processes. Most cases originate from a thyroid gland pathology and are defined as primary hypothyroidism, in other rarer cases it may develop due to lack of TSH stimulation (secondary hypothyroidism) or TRH (tertiary hypothyroidism) (14). When initiated in adulthood, hypoT causes a generalized decrease in metabolism, with slowed heart rate, decreased oxygen consumption and glycosaminoglycan deposits in intercellular spaces, particularly in skin and muscle, leading in extreme cases to the clinical syndrome of myxedema (15). In hypoT, TSH is elevated and the finding of antithyroid antibodies such as antithyroglobulin (ATG) and anti-thyroid peroxidase (ATPO) point to an autoimmune cause (16). The diagnosis of subclinical hypothyroidism (HipoSC) is defined by elevated TSH concentrations with normal T4L and is classified as mild TSH between 4.5-10.0 mIU/L and severe TSH greater than $10 \mathrm{mIU} / \mathrm{L}$ (14). $10.0 \mathrm{mIU} / \mathrm{L}$ and severe TSH greater than $10 \mathrm{mIU} / \mathrm{L}$ (14). The most frequent causes of subclinical hypothyroidism may be: - spontaneous: chronic autoimmune thyroiditis (Hashimoto's) whose prevalence increases with age; - iatrogenic: undertreatment of hypothyroidism after treatment of hyperthyroidism especially with radioactive iodine or surgery; - drugs: amiodarone, lithium and other iodine-containing medications (14-16).

It is well known that TDs are associated with alterations in the lipid profile; this is due to several factors; firstly, HTs are involved in lipid metabolism, stimulating by enzymatic action and $\beta$-adrenergic stimulation the degradation of lipids in adipose tissue, thus favouring the $\beta$-oxidation of lipids at the level of muscle and liver. HT also facilitates the excretion of cholesterol, its conversion to bile acids and accelerates the turnover of low-density lipoproteins (LDL), perhaps by stimulating the synthesis of their receptors or their degradation. That is, these hormones influence all aspects of lipid metabolism, including synthesis, mobilisation and degradation, since, in thyroid disease, dyslipidaemia and metabolic abnormalities coexist in combination with HT-induced haemodynamic alterations, which explains the high risk of cardiovascular disease (17).

A large number of epidemiological studies show increased risk of cardiovascular mortality in both clinical and subclinical hypothyroidism $(18,19)$, but not all studies demonstrate this $(20,21)$. Consistently elevated levels of total cholesterol (Chol), LDL cholesterol (LDL Chol) and triglycerides (TG) have been reported in patients with clinical hypothyroidism (22). In general, these changes tend to reverse with correction of hypothyroidism. On the other hand, the influence of hypoSC on serum lipid levels is less 
evident and some studies have also shown elevated LDLchol levels (23). It is accepted that the determining event in the elevation of LDL-chol is a decrease in intracellular protein synthesis leading to a lower expression of the LDL receptor (24). Treatment of hypothyroidism with levothyroxine reverses this process and lowers serum LDL-chol levels (25). Therefore, this study aims to determine the prevalence of thyroid dysfunction and its relationship with the lipid profile in adult patients and outpatients attending the Regional Hospital of Encarnación during the period January-November 2016.

\section{Materials y Methods}

\section{Type of study}

A descriptive cross-sectional study was carried out, based on a review of medical records.

\section{Population and sample}

A non-probabilistic sample was made up of 250 medical records of outpatients of both sexes, aged between 20 and 80 years, who attended the laboratory service of the Regional Hospital of Encarnación, during the period January-November 2016, with a doctor's order for a health check-up.

Inclusion criteria: Medical records with complete patient data, as well as TSH, T4L, glycaemia and lipid profile determinations were selected.

Exclusion criteria: Those receiving medication that could affect thyroid function, with a personal history of thyroid dysfunction, goitre or thyroid surgery, with autoimmune diseases, those with an infectious, renal or oncological disease, pregnant and diabetic patients, as well as those on antihypertensive treatment were excluded.

\section{Laboratory determinations}

The following determinations were performed: TSH, T4L, which were processed using chemiluminescence methods, with Access DxI 800 equipment (BeckmanCoulter). The ACCESS assay ( $3^{\text {rd }}$ IS) is a paramagnetic particle chemiluminescence immunoassay for the quantitative determination of serum human thyroid stimulating hormone levels, offering 3rd generation TSH results of functional sensitivity $(0.01-0.02 \mu \mathrm{IU} / \mathrm{mL}[\mathrm{mIU} / \mathrm{L}]$ with an interassay $\% \mathrm{CV} \leq 20 \%$ ) for the measurement of TSH (26). Lipid profile and glycaemia were also determined using serum as a sample, samples were processed on automated Beckman Coulter DxC 800 equipment. Cholesterol concentration was measured by a fixed-time end-point method $(27,28)$. Triglyceride determination also used a fixed-time endpoint method (29,30). The HDL-cholesterol and LDL-cholesterol test was determined using a homogeneous two-reagent system. The VLDL-cholesterol was obtained by calculating: VLDL-cholesterol $=$ total cholesterol - (HDL-cholesterol + LDL-cholesterol). The glucose concentration was de- termined by a kinetic method using the Beckman Coulter oxygen electrode. A precise volume of sample is injected into a cuvette containing glucose oxidase solution. The peak rate of oxygen consumption is directly proportional to the glucose concentration in the sample.

\section{Definition of variables}

Age: this was obtained from the date of birth, data from the patient's personal file, and was recorded in years. For the analysis, the variable was treated as a continuous quantitative variable.

Sex: This was used dichotomously: Female, Male.

Euthyroidism: TSH between 0.4 - 4.20 IUU/ml; FT4 between $0.93-1.70 \mathrm{ng} / \mathrm{dl}$.

Clinical hypothyroidism: TSH greater than 4.20 IUU/ $\mathrm{ml}$; FT4 less than $0.93 \mathrm{ng} / \mathrm{dl}$.

Subclinical hypothyroidism: TSH greater than 4.20 IUU/ml; TFT4 between $0.93-1.70 \mathrm{ng} / \mathrm{dl}$.

Clinical hyperthyroidism: TSH less than $0.27 \mathrm{IUU} / \mathrm{ml}$; FT4 greater than $1.70 \mathrm{ng} / \mathrm{dl}$.

Subclinical hyperthyroidism: TSH less than 0.27 IUU/ $\mathrm{ml}$ and FT4 between $0.93-1.70 \mathrm{ng} / \mathrm{dl}$ (26).

Hypertriglyceridaemia: Triglycerides $(\mathrm{Tg}) \geq 150 \mathrm{mg} / \mathrm{dl}$. Hypercholesterolaemia: Cholesterol (Chol) $\geq 200 \mathrm{mg} / \mathrm{dl}$. HDL: HDL cholesterol $<40 \mathrm{mg} / \mathrm{dl}$ in men and $<50 \mathrm{mg} /$ $\mathrm{dl}$ in women (ATP III) (31).

LDL: Optimal < 100 mg/dl. Near optimal 100 - 129 mg/ dl. Borderline $130-159 \mathrm{mg} / \mathrm{dl}$. High $\geq 160 \mathrm{mg} / \mathrm{dl}$

Dyslipidaemia: Total cholesterol $(\mathrm{Chol}) \geq 200 \mathrm{mg} / \mathrm{dl}$ and triglycerides $(\mathrm{TG}) \geq 150 \mathrm{mg} / \mathrm{dl}$, and

Chol LDL $\geq 130 \mathrm{mg} / \mathrm{dl}$. This variable was categorised as a dichotomous variable (YES, NO).

Normal blood glucose: $<100 \mathrm{mg} / \mathrm{dl}$ and impaired fasting blood glucose (IFG) values $\geq 100 \mathrm{mg} / \mathrm{dl}$ and $<126 \mathrm{mg} / \mathrm{dl}$, according to the American Diabetes Association (ADA) (32).

\section{Statistical analysis}

Qualitative variables were described using percentages and $95 \%$ confidence intervals. For quantitative variables, their distributions were determined with the KolmogorovSmirnov normality test and, as appropriate, described by mean and standard deviation or median and 25th and 75th percentiles.

The Student's test was used to compare quantitative variables with a normal distribution. For non-normally distributed variables, the non-parametric Mann Whitney $\mathrm{U}$ test was used. Logistic regression was used to assess the contribution of dyslipidaemia to the occurrence or non-occurrence of thyroid dysfunction.

We worked with a confidence level of $95 \%$ and with a significance of $\mathrm{p}<0.05$.

The statistical programme Statgraphics Centurión XV was used for data analysis and Excel 2010 was used for the elaboration of tables and graphs. 


\section{Ethical challenges}

All patients, whose data were selected, gave their informed consent and the confidentiality of the results has been respected. The work has been endorsed by the hospital where this work was carried out and its bioethics committee.

\section{Results}

Of the 250 medical records studied, 211 were women (84\%) and 39 men (16\%). The median age in men was 39 [35-47] years, while in women it was 36 [32-43] years. Table 1 shows the biochemical characteristics of the individuals studied, for the total sample and their distribution according to gender.

Table 1: Biochemical characteristics of the study sample $(n=250)$.

\begin{tabular}{|c|c|c|c|c|}
\hline Variables & $\begin{array}{c}\text { Total } \\
(\mathrm{n}=250)\end{array}$ & $\begin{array}{l}\text { Femenino } \\
(n=211)\end{array}$ & $\begin{array}{l}\text { Masculino } \\
(n=39)\end{array}$ & p-value \\
\hline Glucose $(\mathrm{mg} / \mathrm{dl})^{b}$ & $85(77-96)$ & $85(77-95)$ & $88(77-96)$ & 0,199 \\
\hline $\begin{array}{l}\text { Total cholesterol } \\
(\mathrm{mg} / \mathrm{dll})^{\mathrm{a}}\end{array}$ & $208 \pm 49$ & $209 \pm 47$ & $202 \pm 57$ & 0,416 \\
\hline $\begin{array}{l}\text { HDL cholesterol } \\
(\mathrm{mg} / \mathrm{dl})^{\mathrm{b}}\end{array}$ & $40(37-45)$ & $41(38-45)$ & $38(33-44)$ & 0,002 ** \\
\hline $\begin{array}{l}\text { LDL cholesterol } \\
(\mathrm{mg} / \mathrm{dl})^{\mathrm{a}}\end{array}$ & $135 \pm 44$ & $136 \pm 44$ & $128 \pm 46$ & 0,412 \\
\hline $\begin{array}{l}\text { VLDL cholesterol } \\
(\mathrm{mg} / \mathrm{dll})^{\mathrm{b}}\end{array}$ & $28(23-39)$ & $27(23-37)$ & $30(21-47)$ & 0,529 \\
\hline $\begin{array}{l}\text { Triglycerides } \\
(\mathrm{mg} / \mathrm{dll})^{\mathrm{b}}\end{array}$ & $\begin{array}{c}\text { 139(111- } \\
187)\end{array}$ & $\begin{array}{c}138(111- \\
186)\end{array}$ & $\begin{array}{c}146(106- \\
220)\end{array}$ & 0,650 \\
\hline $\mathrm{TSH}(\mathrm{UlU} / \mathrm{ml})^{\mathrm{b}}$ & $\begin{array}{c}2,52(1,34- \\
4,71)\end{array}$ & $\begin{array}{c}2,59(1,35- \\
4,95)\end{array}$ & $\begin{array}{c}1,89(1,31- \\
3,46)\end{array}$ & 0,185 \\
\hline $\mathrm{T} 4 \mathrm{~L}(\mathrm{ng} / \mathrm{dl})^{\mathrm{b}}$ & $\begin{array}{c}1,12(0,76 \\
-1,45)\end{array}$ & $\begin{array}{c}1,09(0,74- \\
1,43)\end{array}$ & $\begin{array}{c}1,21(0,87- \\
2,01)\end{array}$ & 0,183 \\
\hline \multicolumn{5}{|c|}{$\begin{array}{l}\text { References: a Results expressed as mean } \pm \text { standard deviation; b Results expressed as } \\
\text { median and } 25 \text { th and } 75 \text { th percentiles; TSH: thyrotropin; T4L: free thyroxine. ** Mann Whitney } \\
\text { U test. }\end{array}$} \\
\hline
\end{tabular}

All patients had normal baseline blood glucose levels with no significant difference according to sex $(p=0.199)$; no patients with $\mathrm{OAG}$ were found. There was a significant difference between men and women for HDL cholesterol. When analysing the thyroid profile, it was observed that $33 \%$ [95\%CI 27-39\%] of the individuals had thyroid dysfunction, the most prevalent being hypothyroidism, in $30 \%$ [95\% CI 24-36\%], with subclinical presentation being the most frequent, while hyperthyroidism was observed in $3 \%$ [95\%CI 1-5\%] of the samples studied; figure 1 shows the data on the prevalence of thyroid dysfunction.

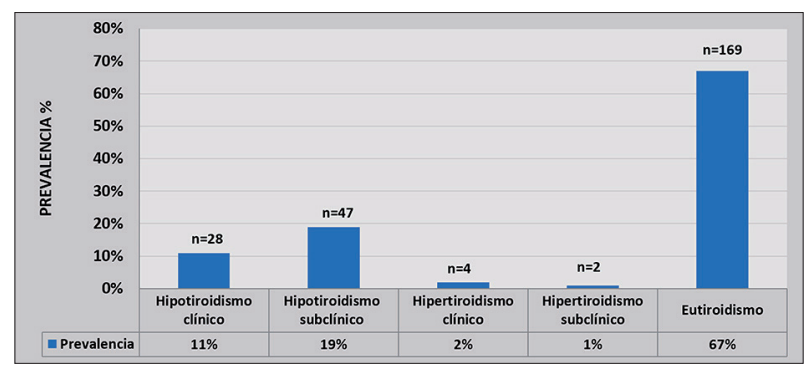

Figure 1: Prevalence of thyroid dysfunction in the samples studied $(n=250)$.
Figure 2 shows the distribution of thyroid dysfunctions according to sex; $34 \%$ [95\% CI 27-40\%] of women and $26 \%$ [95\% CI $14-43 \%$ ] of men had some type of thyroid dysfunction.

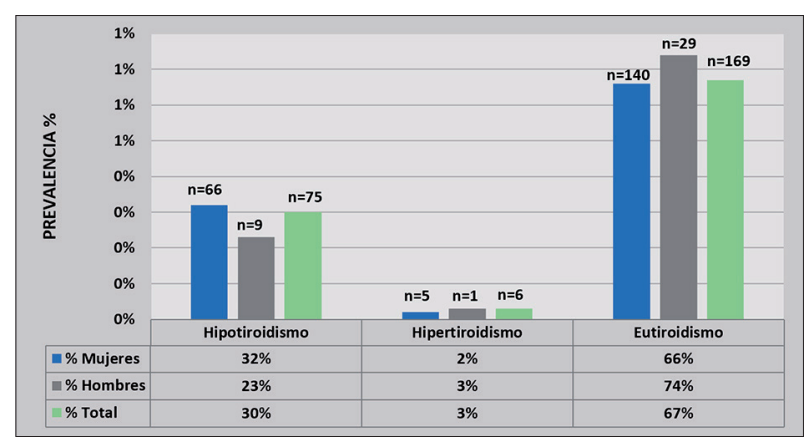

Figure 2: Prevalence of thyroid dysfunction by $\operatorname{sex}(n=250)$.

To determine the behavior of the thyroid states, a comparison was made of the biochemical parameters of hypothyroid and hyperthyroid patients in relation to euthyroid patients, finding in hypothyroidism a difference between means for total cholesterol, LDL cholesterol and a difference between medians for VLDL cholesterol and TSH as shown in table 2 .

Table 2: Comparison of biochemical parameters of hypothyroid and euthyroid patients $(n=250)$.

\begin{tabular}{|c|c|c|c|}
\hline Variables & $\begin{array}{c}\text { Hypothyroidism } \\
n=75\end{array}$ & $\begin{array}{c}\text { Euthyroidism } \\
n=169\end{array}$ & p-value \\
\hline 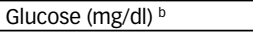 & $84(76-100)$ & $87(77-95)$ & 0,074 \\
\hline 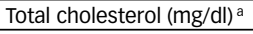 & $229 \pm 38$ & $201 \pm 7$ & $<0,001^{*}$ \\
\hline HDL cholesterol (mg/dl) & $40(36-45)$ & $41(38-46)$ & 0,221 \\
\hline 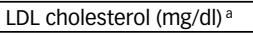 & $154 \pm 35$ & $128 \pm 45$ & $<0,001^{*}$ \\
\hline $\mathrm{VLDL}$ cholesterol $(\mathrm{mg} / \mathrm{dl})^{\mathrm{b}}$ & $32(25-39)$ & $27(21-38)$ & $0,025^{* *}$ \\
\hline Triglycerides $(\mathrm{mg} / \mathrm{dl})^{\mathrm{b}}$ & $156(122-193)$ & 136(106-187) & 0,248 \\
\hline $\mathrm{TSH}(\mathrm{ulU} / \mathrm{ml})^{\mathrm{b}}$ & $6,35(4,95-7,78)$ & $1,81(1,23-2,58)$ & $<0,001^{* *}$ \\
\hline T4L(ng/dl) ${ }^{\mathrm{b}}$ & $0,97(0,71-1,79)$ & $1,16(0,78-1,43)$ & 0,141 \\
\hline
\end{tabular}

For hyperthyroidism, a difference between mediums was found for total cholesterol, with average serum levels being significantly lower among patients with hyperthyroidism compared to the group without thyroid dysfunction, and differences were also found for median triglycerides and TSH as shown in table 3.

Table 3: Comparison of biochemical parameters of hyperthyroid and euthyroid patients $(n=250)$.

\begin{tabular}{|c|c|c|c|}
\hline Variables & $\begin{array}{c}\text { Hypothyroidism } \\
n=75\end{array}$ & $\begin{array}{c}\text { Euthyroidism } \\
n=169\end{array}$ & $\mathrm{p}$-value \\
\hline Glucose $(\mathrm{mg} / \mathrm{dl})^{b}$ & $83(77-96)$ & $87(77-95)$ & 0,971 \\
\hline Total cholesterol $(\mathrm{mg} / \mathrm{dl})^{\mathrm{a}}$ & $151 \pm 50$ & $201 \pm 7$ & $0,016^{*}$ \\
\hline HDL cholesterol (mg/dl) & $37(30-46)$ & $41(38-46)$ & 0,288 \\
\hline LDL cholesterol $(\mathrm{mg} / \mathrm{dl})^{\text {a }}$ & $79(59-105)$ & 122(95-158) & $0,046^{* *}$ \\
\hline VLDL cholesterol $(\mathrm{mg} / \mathrm{dl})^{\mathrm{b}}$ & $20(16-25)$ & $27(21-38)$ & 0,055 \\
\hline 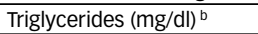 & $99(81-126)$ & 136(106-187) & $0,041^{* *}$ \\
\hline TSH $(\mathrm{ulU} / \mathrm{ml})^{\mathrm{b}}$ & $0,11(0,04-0,15)$ & $1,81(1,23-2,58)$ & $<0,001^{* *}$ \\
\hline $\mathrm{T} 4 \mathrm{~L}(\mathrm{ng} / \mathrm{dl})^{\mathrm{b}}$ & $1,91(1,21-2,05)$ & $1,16(0,78-1,43)$ & 0,073 \\
\hline
\end{tabular}

Dyslipidaemia was found in $34 \%$ of the population sample, $56 \%(n=48)$ corresponded to patients with thyroid disorders Logistic regression was used to assess the contri- 
bution of dyslipidaemia to the occurrence or not of thyroid dysfunction; for hypothyroidism $\mathrm{OR}=3.24(1.81-5.81)$ and $\mathrm{p}<0.001$; for hyperthyroidism $\mathrm{OR}=0.26(0.03-2.35)$ and $\mathrm{p}=0.205$, finding that dyslipidaemia is associated with hypothyroidism.

\section{Discussion}

In recent years, the diagnosis of thyroid dysfunction has become more reliable and safer due to the development of more sensitive methods for the determination of thyroid hormones, in particular T3, T4 and TSH. This has contributed to the recognition of subclinical forms of the disease, allowing diagnosis to be reached more frequently and more efficiently (33). However, little information has been found on the prevalence of these disorders in Paraguay, which is why this study is so important, as it provides data on the behaviour of these diseases in the population.

Different approaches to screening for thyroid dysfunction have been proposed, with the American Thyroid Association recommending thyroid function measurements in all persons over 35 years of age and then every five years if normal, while the American College of Physicians recommends screening in persons over 50 years of age with one or more general symptoms that could be caused by thyroid disease $(8,34,35)$.

In the present study, individuals of both sexes participated, with a higher frequency of women (84\%); with regard to biochemical characteristics, all had fasting blood glucose levels within the reference values, with no significant difference according to sex $(\mathrm{p}=0.199)$; a significant difference by sex was only observed when HDL cholesterol was assessed $(\mathrm{p}=0.002)$. TSH and T4L values were higher than those obtained in other studies such as those of Builes et al. in Bogotá (35) and those found by Kolbe in a study on Thyroid dysfunction and cardiovascular risk factor in an adult population in Obligado, Paraguay (36), but similar to those found by Maldonado Araque in Spanish adults (37).

In relation to the diagnosis of thyroid dysfunctions, the most sensitive methods at present, the so-called third generation methods, capable of detecting TSH levels of up to $0.01-0.03 \mathrm{uIU} / \mathrm{ml}(38)$, have allowed the laboratory to find both the clinical form, but above all the subclinical ones that could often go unnoticed due to the absence of clear symptoms. The ranges of these hormones in euthyroid individuals may vary slightly between different age groups and between different laboratories. In this study, we took as reference values those recommended by the National Academy of Clinical Biochemistry -NACB (26), finding a total prevalence of $33 \%$ of TD, according to the WHO, between 8 and $10 \%$ of the world's population have thyroid function disorders (17). In another study carried out in a Costa Rican adult population, Guevara et al. found $18.7 \%$ of thyroid dysfunctions (11), while Vera et al. in the national hospital of Itaguá-Paraguay found 34\% of thyroid disorders (51), similar to the data obtained in this study, in contrast to the $24.4 \%$ reported by Kolbe (36)

There are several factors that affect each population differently and are responsible for the large heterogeneity shown in prevalence rates between different populations; it should be taken into consideration that thyroid hormone levels vary with age, method used and population studied, which makes it necessary to have own reference values, from each laboratory, in different age ranges and from the indigenous population.

In the present study, the prevalences of thyroid dysfunctions found were higher than those observed in a study carried out in the Hospital de Clínicas in Buenos Aires (39) and similar to the values found in Obligado-Paraguay (36) and in the Hospital Nacional de Itaguá-Paraguay, but they all coincide in that the frequency of hypoSC is higher than hypoT, which reflects the need to recognize these pathologies and establish early treatment, in order to avoid more serious and costly situations for public health.

Population-based prevalence studies assessing the frequency of thyroid dysfunction in the general population, including the NHANES III study $(n=16,533)$, reported a $4.5 \%$ hypoSC and a $0.5 \%$ hyperT rate. On the other hand, the Colorado study $(n=25,862)$ showed a prevalence of $9.5 \%$ and $2.2 \%$ of hypoT and hyperSC $(40,41)$.

The potentially harmful effects associated with hyperSC are the main reasons why European guidelines which now recommend initiating treatment of this clinical condition (42). Recommendations consider treatment especially for adults with subclinical hyperthyroidism with TSH levels below $0.1 \mathrm{mIU} / \mathrm{L}$, in order to avoid cardiovascular consequences (42).

Several population-based studies, carried out in asymptomatic groups, have reported a higher frequency of hypothyroidism in women, especially in the subclinical form compared to the overt form, with a predominance of women in our study population, 211 (84\%) compared to 39 $(16 \%)$ men, with a higher frequency in women in all TDs. Studies such as Whickham's reported abnormally high TSH in $7.5 \%$ of women and $2.8 \%$ of men (43) and in the Birmingham study in women over 60 years of age, hypoT was found in $2 \%$ and mild in $9.6 \%$; furthermore, several studies found a higher prevalence in women particularly in the sixth decade and up to $16 \%$ for hypoSC $(44,45)$. As women predominate in our population, as they are the ones who attend more health check-ups, we could not say that this coincidence with the literature is accurate.

Dyslipidaemia was found in $34 \%$ of the population sample, in which more than half had thyroid disorders, with a significant association with hypothyroidism $(p<0.001)$. In contrast, no association was found with hyperthyroidism, which is in agreement with some authors who refer to hypothyroidism as a recognized cause of secondary dyslipidaemia $(46,47)$. In overt hypothyroidism, the increase in total cholesterol is above $50 \%$ of the values found in 
euthyroid subjects; This can be attributed primarily to the increase in LDL-chol and secondarily to the increase in LDL and VLDL-chol fractions. The main cause of hypercholesterolaemia in these patients is the decreased clearance of LDL by its receptor, based on decreased LDL receptor gene expression in fibroblasts, hepatocytes and other tissues (45).

In hypo $\mathrm{T}$ there is a predisposition to cardiovascular problems, as there is a decrease in myocardial contractility which favors atherosclerotic processes, there is a reduction in lipolysis and a consequent increase in serum lipid levels (48). Rodondi et al (49) have found elevated concentrations of total cholesterol and LDL-cholesterol in populations with hypoSC compared to euthyroid groups, as in the present study it was found that hypothyroid patients had a significant difference between the means and medians of serum levels of total cholesterol, LDL-cholesterol and VLDL-cholesterol, with higher values than euthyroid patients. Similar results were reported by Villalba Rinck Hansen et al (47), in a population of hypothyroid adult women from Posadas. In terms of the comparison of medians between hyperthyroidism and euthyroidism, significant differences were found between total cholesterol, LDL cholesterol and TG, but lower serum values were obtained with respect to euthyroid patients; in hyperthyroidism, an increase in lipolysis leads to weight loss in patients, while lipolysis leads to lower concentrations of total cholesterol and LDL cholesterol (46).

Many studies indicate the benefits of treatment for TD patients, such as improvements in lipid profile, prevention of early cardiovascular events, reversal of haemodynamic disturbances and neuropsychiatric symptoms, prevention of atrial fibrillation and development of osteoporosis with hormone replacement therapy (50). Thyroid hormones play an important role in lipid synthesis, mobilization and metabolism, as reported in Colorado (USA), where total cholesterol and LDL-cholesterol were observed to increase as TSH levels rose (41).

In Paraguay there are few data or studies on thyroid dysfunction and its relationship with other parameters such as the lipid profile; one explanation could be the discontinuous supply of reagents for the determination of the thyroid profile due to a lack of economic resources, making it difficult to have statistical data for our population. Consequently, there is a difficulty in early identification of these hormonal alterations and their subsequent treatment, since the reduction of comorbidities associated with thyroid dysfunction disorders would contribute to improving the life quality of these patients, reversing their clinical manifestations and achieving a longer life expectancy.

\section{Conclusions}

The prevalence of clinical hypothyroidism in the studied individuals was $11 \%$ and of subclinical hypothyroi- dism was $19 \%$. The prevalence of clinical hyperthyroidism was $2 \%$ and of subclinical hyperthyroidism was $1 \%$.

When analyzing hormonal variables, 33\% of this population sample had elevated TSH values and 3\% had decreased TSH values; the majority had values within the recommended range, and the most frequently detected thyroid dysfunction was subclinical hypothyroidism.

Hypothyroid patients have significantly higher serum values of total cholesterol, LDL-cholesterol and VLDLcholesterol compared to euthyroid patients.

Hyperthyroidism presents significant differences for total cholesterol, LDL cholesterol and triglycerides, with respect to euthyroid patients, presenting lower serum values than euthyroid patients.

Dyslipidaemia is associated with hypothyroidism, so screening for hypothyroidism in patients with dyslipidaemia is recommended in order to contribute to the reduction of morbidity and mortality from cardiovascular events.

\section{References}

1. Guyton A. Hormonas metabólicas tiroideas. In Guyton A. Tratado de Fisiología Médica $12^{\mathrm{a}}$ ed. España: Elsevier Saunders; 2011. p. 907-919.

2. Jerome M, Hershman MD, Geffen D. Generalidades sobre la función tiroidea - Trastornos endocrinológicos y metabólicos. Manual MSD [Internet]; 2018 [Consultado 04 diciembre 2020]. Disponible en: https:// www.msdmanuals.com/es/professional/trastornosendocrinol $\% \mathrm{C} 3 \% \mathrm{~B} 3$ gicos-y-metab $\% \mathrm{C} 3 \% \mathrm{~B} 31 \mathrm{cos} /$ trastornos-tiroideos/generalidades-sobre-lafunci $\% \mathrm{C} 3 \% \mathrm{~B} 3 n$-tiroidea.

3. Alejandro B. TRAPS. Programa de Capacitación Terapéutica racional en atención primaria de salud [Internet]. 2015 [Consultado 04 diciembre 2020]. Disponible en: http://186.33.221.24/files/Unidad_2_MCF_CUS_con_ tapa_julio_WEB.pdf.

4. Cooper DS, Ladenson PW. Greenspan. Endocrinología básica y clínica, 9th ed.: McGraw-Hill Medical; 2010.

5. Ibáñez Toda L, Salas M. Actualización en Patología Tiroidea. Curso de Actualización Pediatría. Madrid: AEPap; 2017.

6. López-Tinoco C, Roldan Caballero P, Gavira LM, Aguilar Diosdado M. Elsevier; Medicine-Programa de Formación Médica; Patología Tiroidea [Internet]. 2012 [Consultado 05 diciembre 2020]. Disponible en: https://www.sciencedirect.com/science/article/pii/S0304541212703888.

7. Wartofsky L, Glinoer D, Solomon D, Nagataki S, Lagasse R, Nagayama $\mathrm{Y}$, et al. Differences and similarities in the diagnosis and treatment of Graves disease in Europe, Japan and the United States. Thyroid. 1990; 1(129-35).

8. Ladenson PW, Singer PA, Ain KB, Bagchi N, Bigos ST, Levy LG, et al. American Thyroid Association Guidelines for detection of thyroid dysfunction. Arch Intern Med. 2000; 160:(1573-5).

9. Liberman c. Enfermedad Tiroidea Subclinica.Revisión 
y Enfoque Clínico. Rev Med. Clinica Condes. 2013:; 24(5):(748-753).

10. Wardle CA, Fraser WD, Squire CR. Pitfalls in the use of thyrotropin concentration as a firstline thyroid-function test. Lancet. 2001; 357:(1013-4).

11. Guevara- Sanchez $O$, Holst-Schumache $I$, Boza-Oreamuno $S$, Barrantes-Santamaría M, Chinchilla-Monge R, Alvarado-Ulate P. Disfunción tiroidea subclínica en población adulta costarricense. An Fac med. 2015; 76(4): 333-338.

12. Biondi B, Bartalena L, Cooper $D$, Hegedüs L, Laurberg $P$, Kahaly $\mathbf{G}$. The 2015 European Thyroid Association Guidelines on Diagnosis and Treatment of Endogenous Subclinical Hyperthyroidism. European Thyroid Journal. 2014; ; 4: (149-163.).

13. Reid J, wheleer s. Hyperthyroidism: Diagnosis and Treatment. Am Fam Physician. 2005; 72:623-30, (6356.f).

14. Augustovski F, Botargues M. Problemas Tirodeas en la Atención Ambulatoria. Curso Anual de Medicina Familiar y Atención Médica Primaria. BS.As: Hospital Italiano de Buenos Aires; 2000.

15. Henderson KE, Mc Gill JB, Clutter WE, Baranski TJ. Manuales Washington de Especialidades clínica. Endocrinología. 3rd ed. Barcelona.Spain: LIPPINCOTT WILLIAMS WILKINS; 2015.

16. Gaintonde D, Rowley K, Sweeney L. Hypothyroidism: An Update. Am Fam Physician [Internet]. 2012 [Consultado 04 diciembre 2020]; 86(3):244-251 Disponible en: https://www.aafp.org/afp/2012/0801/p244.pdf.

17. Gonzalez M, Gil E, Younes Y, Perelli T, Calzolajo A, Superlano V, et al. Disfunción Tiroidea y su relación con el perfil lipídico e indices aterogénicos en individuos antes y despúes de la tiroidectomía. Revista Venezolana de Endocrinología y Metabolismo. 2014; 12(1).

18. Hak A, Pols V , Drexhage H, Hofman A, et.al. Subclinical hypothyroidism is an independent risk factor for aterosclerosis and myocardial infarction in elderly women. The Rotterdam study. Ann Intern. Med. 2000; 132: ( 270-278).

19. Imaizumi M, Akahoshi M, Ichimaru S, Nakashima E, Hilda A. Risk for ischemic heart disease and all-cause mortality in subclinical hypothyroidism. J Clin Endocrinol Metab. 2004; 89: (3365-3370).

20. Volzke, schwahn C, Wallaschfski H, Dorr M. The association of thyroid dysfunction with all cause and circulatory mortality: Is there a causal relationship?. J Clin Endocrinol Metab. 2007; 92: (2421-2429).

21. Dorr M, Voolzke H. Cardiovascular morbidity and mortality in thyroid dysfunction. Minerva Endocrinol. 2005; 30: (199-216).

22. Wartofsky L. Cardiovascular risk and subclinical hypothyroidism: Focus on lipids and new emerging risk factors. What is the evidence? Thyroid. 2007; 17:(1075-1084).

23. Biondi B, Cooper D. The clinical significance of subcli- nical thyroid dysfunction. EndocrRev. 2008; 29: (76131).

24. Duntas L, Mantzou E, Koutras D. Circulating levels of oxidized lowdensity lipoprotein in overt and mild hypothyroidism. Thyroid. 2002; 12.

25. Bengel F, Nekolla S, Ibrahim T, Weniger C, Ziegler , Schwaiger M. Effect of thyroid hormones on cardiac function, geometry and oxidative metabolism assessed noninvasivaly by positrón emission tomography and magnetic resonance imaging. J Clin Endocrinol Metab. 2000; 85: (1822-1827).

26. Demers LM, Spencer CA. Laboratory Support for the Diagnosis and Monitoring of Thyroid Disease. Washington: The National Academy of Clinical Biochemistry; 2002.

27. Allain CC, Poon LS, Chan Cs, et.al. Enzymatic Determination of Total Serum. Cholesterol. Clin. Chem. 1974; 20/4(470-475): 20:470.

28. Röschlau P, Bernt E, Gruber W. Enzymatische Serum (Enzymatic determination of total cholesterol in serum). Z.Klin. Chem. Klin Biochem. 1974; 12(9) (403-407): 12:226.

29. Bucolo G, David H. Quantitative determination of serum triglycerides by the use of enzymes. Clin. Chem. 1973; 19(5) (476-482): 19:476

30. Pinter JK, Hayashi JA, Watson JA. Enzymic assay of glycerol, dihydroxacetone, and glyceraldehyde. Arch. Biochem Biophys. 1967;121(2): 121:404.

31. Rubio MA, Moreno C, Cabrerizo L. Guías para el tratamiento de las dislipemias en el adulto: Adult Treatment Panel III (ATP-III). Endocrinología y nutrición. 2004; 51(5):254-255.

32. ADASOMCiD. Classificatión and Diagnosis of Diabetes: Standars of Medical Care in Diabetes. Diabetes Care 2020; 43(1) (14-32).

33. Le Fevre M. on behalf of the U.S. Preventive Services Task Force. Screening for Thyroid Dysfunction: U.S. Preventive Services Task Force Recommendation Statement [Internet]. 2016 [Consultado 10 diciembre 2020]. Disponible en: http://annals.org/article. aspx? articleid $=2208599$.

34. U.S preventive Services Task Force. Screening for thyroid disease: Recommendation Statement. Am Fam Physician; 2004.

35. Builes CA, Rosero o, García J. Evaluación de disfunción tiroidea según TSH en una población de Bogotá [Internet]. 2006 [Consultado 15 diciembre 2020]. Disponible en: http://www.scielo.org.co/pdf/amc/v31n2/ v31n2a4.pdf.

36. Kolbe Dickel L. Disfunción Tiroidea y Factores de Riesgo Cardiovascular en adultos de la ciudad de ObligadoParaguay [Tesis de especialización en internet]. Posadas [Argentina]: Universidad Nacional de Misiones; 2019 [consultado 04 enero 2021]. Disponible en: http:// www.fceqyn.unam.edu.ar/especializacionbioquimicaclinica/index.php/tesis. 
37. Maldonado Araque c. Prevalencia de disfunción tiroidea en la población española. [Internet]. 2017 [Consultado 10 enero 2021]. Disponible en: https:// riuma.uma.es/xmlui/bitstream/handle/10630/15135/ TD_MALDONADO_ARAQUE_Cristina. pdf? sequence $=1$ \&isAllowed $=y$.

38. 38. Franklyn J, Black E, Betteridge J, Sheppard M. Comparision of second and third generation methods for measurement of serum thyrotropin in patients receiving thyroxine. J Clin Endocrinol Metab. 1994; 78: Mayo; 11(5): 1368-71.

39. 39. Urciuoli C, Abelleira E, Balonga MC, Arevalo de Cross G, Schmidt A, Sala M, et al. Prevalencia de enfermedades tiroideas en una población del área metropolitana de Buenos Aires. Revista Argentina de endocrinología y metabolismo. 2016; 53(2):67-72.

40. 40. Hollowell J, Stachling N, Flanders D, Hannon W, Gunter E, spencer C, et al. Serum TSH, T4, and Thyroid Antibodies in the United States Population (1988 to 1994): National Health and Nutrition Examination Survey (NHANES III). The Journal of Clinical Endocrinology \& Metabolism. 2002; 87(2):489-499.

41. Canaris G, Manowitz N, Mayor G, Ridgway E. The Colorado thyroid disease prevalence study. Arch Intern Med. 2000; 160: 526-34.

42. Association of Clinical Biochemistry, British Thyroid Association and British Thyroid Foundation. UK Guidelines for the use of thyroid function tests. London: ACB and BT. [Internet]. 2006 [Consultado 08 enero 2021]. Disponible en: https:/www.british-thyroid-association.org/sandbox/bta2016/uk_guidelines_for_the_use_of_thyroid_ function_tests.pdf.
43. Vanderpump $\mathbf{M}$, Turnbridge $\mathbf{W}$, French J, Appleton $\mathbf{D}$, Bates $\mathbf{D}$, Clark $\mathrm{F}$, et al. The incidence of thyroid disorders in the community: a twenty-year follow-up of the Whickham Survey. Clin Endocrinol (Oxf) [Internet]. 1995 [Consultado 18 enero 2021]; 43(1):55-68. Disponible en: https://www.ncbi.nlm.nih.gov/pubmed/7641412.

44. Roman DDL, Gónzalez Peláez JL, Aller R, Gónzalez Sagredo L, Cuellar M, Terroba C. Hipotiroidismo: implicaciones clínicas y económicas en un área de salud. An.Med. Interna(Madrid). 2003; 20(3).

45. Tercer consenso argentino sobre patologías endocrinológicas. Disfunción tiroidea subclínica. RAEM. 2009; 46(4).

46. Duntas LH, Wartofsky L. Riesgo cardiovascular e hipotiroidismo subclínico: Enfoque y nuevos factores de riesgo emergentes. ¿Qué es la evidencia? Tiroides. 2007; 17(11).

47. Villalba Rinck Hansen M, Haseitel M, Martinez M, Bonneau GA. Características Clínicas y Bioquímicas al momento del diagnóstico de Hipotiroidismo en mujeres adultas. RECy T. 2019; 31(105-110).

48. Devdhar M, Ousman Y, Burman K. In Hypothyroidism. Endocrinol Metab Clin north Am.; 2007; 36(3):595-615.

49. Rodondi N, Newman A, Vittinghoff E, de Rekeneire N, Satterfield S, Harris T, et al. Subclinical hypothyroidism and the risk of heart failure, other cardiovascular events, and death. In Arch Intern Med. 2005;165(21):2460-6.

50. Monzani F, Di Bello V, Caraccio N, Bertini A, Giorgi D, Giusti C. Effect of levothyroxine on cardiac function and structura in subclinical hypothyroidism: a double blind, placebo-controlled study. In J Clin Endocrinol Metab. 2001;86(3):1110-5. 